\title{
Molecular and cellular mechanisms of diversity within grapevine varieties
}

\author{
F Pelsy ${ }^{1,2}$ \\ ${ }^{1}$ INRA, UMR1131, F-68000, Colmar, France and 'Université de Strasbourg, UMR1131, F-67000, Strasbourg, France
}

\begin{abstract}
A grapevine variety consists of an array of clones descended by vegetative propagation from a single selected vine grown from a single seedling. A majority of the clones within a variety are identical, but some can show divergent genotypes and, to some extent, divergent phenotypes. Polymorphism results mainly from somatic mutations that occur naturally during plant growth. Various types of mutations were shown to be responsible for genetic diversity among clones: point mutations, large deletions, illegitimate recombination or variable number of repeats in microsatellite sequences.
\end{abstract}

In most cases, somatic mutations do not affect the whole plant; rather, they affect only one cell layer, leading to periclinal chimeras. Such structures do not threaten the plant's fitness and are stable through vegetative propagation. Occasionally, cellular rearrangements in the chimera lead to homogenization of the genotype of the whole plant. Through these molecular and cellular mechanisms, the genotypes of clones drift over time and grapevine varieties evolve.

Heredity (2010) 104, 331-340; doi:10.1038/hdy.2009.161; published online 25 November 2009

Keywords: Vitis vinifera L; diversity; clones; somatic mutation; chimera; berry skin color

\section{Introduction}

Grapes, one of the oldest agricultural crops, are cultivated to produce table fruits, dried fruits, juice and wine. The number of cépages referenced as varieties held in germplasm collections around the world is estimated at 10000 (Alleweldt and Dettweiler, 1994), most of them belonging to the European species Vitis vinifera L. The large number of varieties is probably the result of several processes: multiple domestication centers from local wild Vitis silvestris vines (Arroyo-Garcia et al., 2006), subsequent crosses between domesticated and local wild vines, the old practice of growing seedlings from spontaneous crosses and, to a lesser extent during the last century, conventional breeding. Crosses are attested by the pedigree reconstitution of several varieties such as Cabernet Sauvignon, which is a progeny of Cabernet franc and Sauvignon blanc (Bowers and Meredith 1997), and Chardonnay and Gamay, which are progenies of Pinot and Gouais (Bowers et al. 1999).

After selected seedlings have been multiplied by vegetative propagation, a conservative strategy, used to obtain copies of the original parental stock by cutting, layering or grafting. The copy of the original plant is said to be a clone. This process creates clones that are genetically identical to the parent plant, provided that somatic mutation has not occurred in the regenerative cells that gave rise to the clone. Vegetative propagation has been the preferred method to perpetuate selected grapevine varieties since Roman times, as reported in books III and IV of the Roman agricultural writer

Correspondence: Dr F Pelsy, INRA-COLMAR, UMR 1131, 28 rue de Herrlisheim, COLMAR 68000, France.

E-mail: frederique.pelsy@colmar.inra.fr

Received 31 July 2009; revised 14 October 2009; accepted 20 October 2009; published online 25 November 2009
Columella (Robinson, 2006). Varieties are currently considered to consist of clones that share common morphological traits. Nevertheless, clones showing phenotypic variations are often observed and considered as part of the same variety within an accepted range of phenotypes. When clones of the same variety have phenotypes different enough to be grown for the production of different wines, they are grouped in different cultivars (Boursiquot and This, 1999). Currently, most French vineyards are planted with a small number of clones certified by French government authorities and propagated by grafting onto rootstock (Vinifhor, 2007).

In this article, we review the current knowledge of genetic diversity between grapevine clones. We discuss naturally occurring variations that have been maintained by human selection and describe genetic mutations underlying polymorphic traits, as well as cellular mechanisms leading to the propagation of mutations during meristem development. Finally, we attempt to identify factors that may influence clone evolution.

\section{Microsatellite polymorphism within varieties}

Grapevine varieties consist of arrays of clones descended by vegetative propagation from a single selected vine originally grown from a single seedling. A majority of the clones within a variety are identical, but some can show divergent genotypes and even divergent phenotypes. Differences between clones can result from epigenetic modifications in response to the environment (Kaeppler et al., 2000) or from the presence of phytopathological agents such as viruses and viroids (Walter and Martelli, 1998). However, clonal polymorphism is mainly due to mutations that occur naturally during grapevine growth (Hartmann et al., 2001). Mutation frequencies and rates in vegetatively propagated woody 
plants are still relatively unknown, but within major clades, trees and shrubs are known to evolve more slowly than related herbaceous plants (Smith and Donoghue, 2008).

Microsatellite markers, which are highly transferable and co-dominant, have been used extensively to reveal polymorphisms between and within grapevine varieties (Thomas and Scott, 1993; Sefc et al., 2001; Merdinoglu et al., 2005). These markers, which are among the most variable types of genomic DNA sequences, are based on tandem repeats of short (1-6bp) units flanked by highly conserved stretches. Microsatellite marker polymorphisms are derived mainly from variability in the number of repeats in the microsatellite stretch, and thus in allele length, as opposed to variations in the primary sequence (Ellegren, 2004). Slippage of DNA polymerase during replication seems to have a major role in the generation of mutations in microsatellite sequences (Eisen, 1999).

With an average of 8.6 alleles per marker (Pelsy, 2007) and a maximum of 23 alleles within the species $V$. vinifera (This et al., 2004), such markers are highly informative for determining the heterozygosity level of grapevine varieties. This level ranges from 0.47 for Tannat (González-Techera et al., 2004) to 0.87 for Pinot noir and Riesling (Pelsy et al., submitted), with an average of 0.77 (Aradhya et al., 2003). Thanks to the high heterozygosity of grapevine varieties, microsatellite markers present an efficient means to identify grape varieties. In contrast, they generally fail to distinguish between highly similar clones. For example, 84 microsatellite markers revealed genetic similarity levels over $97 \%$ in a set of 59 Cabernet Sauvignon clones collected in seven countries (Moncada et al., 2006), and 50 microsatellite markers revealed genetic similarity levels over $96 \%$ in a set of 145 clones belonging to five Pinot cultivars (Hocquigny et al., 2004). However, these Cabernet Sauvignon and Pinot clones showed polymorphisms and were grouped into 22 and 14 different genotypes, respectively. In both varieties, the detected polymorphisms affected a limited number of loci and mainly resulted from the addition of a new allele to the genotype shared by the highest number of clones. Thus, these markers are important for ascertaining the clonality of vines selected in the field and preserved in repositories, and for efficiently discarding misidentified samples.

\section{Phenotypic diversity}

Exons account for $6.9 \%$ of the grapevine genome, and introns and intergenic sequences make up 36.7 and $34.7 \%$ of the genome, respectively (Jaillon et al., 2007). It could, therefore, be expected that most of the somatic mutations that occur during plant growth would have no effect on phenotype, although they could be identified at the molecular level. However, mutations can occasionally modify phenotypic traits. This is why bud sports, for example, a leaf, shoot or bunch that clearly differs from the rest of the plant, can appear on stocks. Bud sports can be vegetatively propagated to grow new plants, which all retain the genetic difference as a new type of clone. Bud sports have been widely exploited by vine growers as a source of diversity for wine grapes and table grapes (Table 1). Variant traits may include color or flavor, date of ripening, canopy growth, size and compactness of bunches or productivity. The Pinot variety typifies clonal phenotypic diversity and shows an abundant panel of phenotypes referenced as distinct Pinot cultivars. The high degree of diversity in Pinot manifests in traits such as berry color (for example, Pinot noir, Pinot gris and Pinot blanc), pigmented skins and pulp (Pinot teinturier), yield level (for example, Pinot fin vs Pinot moyen), hairiness of apex and expanding leaves (for example, Pinot meunier), canopy growth (for example, Pinot droit), absence of wax on berries (for example, Pinot moure) or cluster architecture.

Other traits, such as berry and wine aroma, can also be affected by phenotypic variations. For instance, two certified clones of Chardonnay are available in Burgundy that produce wines with different aromatic profiles. Chardonnay 76 is specified as being neutral, whereas Chardonnay 809 is distinguished by its 'muscat' aroma. This aroma is due to the production of linalool at significantly higher concentrations (Figure 1). Similarly, Savagnin clones grown to produce either aromatic or neutral wines (Pacottet, 1903) are classified into three distinct cultivars in the French official catalogue of grape varieties: Gewurztraminer (pink berries/aromatic wine), Savagnin rose (pink berries/neutral wine) and Savagnin blanc (also known as Traminer) (white berries/neutral wine) (Institut Français de la Vigne et du Vin, 2007). The aroma of Gewurztraminer is the result of its geraniol content, which is far higher than that of Savagnin rose over all ripening stages (Figure 1) (Duchêne et al., 2009). Moreover, the aromatic qualities of Chardonnay 809 and Gewurztraminer were shown to be heritable as single Mendelian traits in the self-progenies (Duchêne et al., 2009).

Sensitivity to disease is also susceptible to clonal variation. Investigations into Syrah decline have identified large-scale differences in symptom expression between different clones. Three phenotypic groups of Syrah clones were thus identified, one showing very few symptoms, another with moderate sensitivity and one with highly sensitive clones. Expression of the disease symptoms is accentuated when clones are grafted onto two rootstocks (110R and 99R), but it is not significantly different when grafted onto other rootstocks (RenaultSpilmont et al., 2007).

\section{Mutations causing phenotypic clonal variations}

The most well-documented polymorphisms leading to various phenotypes within varieties are those that affect berry color. Clonal diversity in berry color is recorded for black-fruited varieties such as Aramon, Grenache, Pinot or Terret, for which certified clones are available for black, bronze or grey and white varieties (Institut Français de la Vigne et du Vin, 2007), as well as for Cabernet Sauvignon (Walker et al., 2006). Pigmented clones are also available for white-fruited varieties such as Savagnin, Chardonnay or Chasselas. In Brazil, three economically important cultivars differing in berry pigmentation are somatic mutants derived from the green-berried table grape variety Italia. Rubi is a cultivar originated from a light-rose-skinned berried bud sport of Italia, and Benitaka is from an Italia bud sport with more intensely rose-skinned berries. 
Table 1 Grapevine varieties and clones described in this review

\begin{tabular}{|c|c|c|c|c|}
\hline Varietal group & Varieties or variants & Phenotype & Clonality ascertaining & References \\
\hline \multirow{3}{*}{$\begin{array}{l}\text { Cabernet } \\
\text { Sauvignon }\end{array}$} & Cabernet Sauvignon & Black-skinned berries & & \\
\hline & Malian & Bronze-skinned berries & $\begin{array}{l}\text { Bud sport of Cabernet } \\
\text { Sauvignon }\end{array}$ & Boss et al., 1996; Walker et al., 2006 \\
\hline & Shalidan & White-skinned berries & Bud sport of Malian & \\
\hline \multirow[t]{3}{*}{ Chardonnay } & $\begin{array}{l}\text { Chardonnay } \\
\text { blanc }\end{array}$ & $\begin{array}{l}\text { White-skinned berries/ } \\
\text { neutral aroma }\end{array}$ & & \\
\hline & Chardonnay muscaté & $\begin{array}{l}\text { Rosy-skinned berries / } \\
\text { aromatic }\end{array}$ & $16 \mathrm{SSR}$ & Duchêne et al., 2009 \\
\hline & Chardonnay rose & $\begin{array}{l}\text { Rosy-skinned berries / } \\
\text { neutral aroma }\end{array}$ & $\begin{array}{l}\text { Bud sport of } \\
\text { Chardonnay blanc }\end{array}$ & This et al., 2007 \\
\hline \multirow[t]{5}{*}{ Italia } & Italia & Green-skinned berries & & \\
\hline & Ruby Okuyama & Light-rosy-skinned berries & Bud sport of Italia & Kobayashi et al., 2004 \\
\hline & Rubi & Light-rosy-skinned berries & Bud sport of Italia & Oliveira Collet et al., 2005 \\
\hline & Benitaka & Rosy-skinned berries & Bud sport of Italia & Azuma et al., 2009 \\
\hline & Brasil & $\begin{array}{l}\text { Black-skinned and } \\
\text { red-fleshed berries }\end{array}$ & Bud sport of Benitaka & Oliveira Collet et al., 2005 \\
\hline \multirow{2}{*}{$\begin{array}{l}\text { Muscat } \\
\text { d'Alexandria }\end{array}$} & Muscat d'Alexandria & White-skinned berries & & \\
\hline & Flame Muscat & Red-skinned berries & $\begin{array}{l}\text { Bud sport of Muscat } \\
\text { d'Alexandria }^{\text {'Al }}\end{array}$ & Kobayashi et al., 2004 \\
\hline \multirow[t]{5}{*}{ Pinot } & Pinot noir & $\begin{array}{l}\text { Glabrous leaves/ } \\
\text { black waxed berries }\end{array}$ & & \\
\hline & Pinot moure & No wax berries & 50 SSR & Hocquigny et al., 2004 \\
\hline & Pinot meunier & Hairy leaves & $50 \mathrm{SSR}$ & Franks et al., 2002 \\
\hline & Pinot gris & Red-grey-skinned berries & $50 \mathrm{SSR}$ & $\begin{array}{l}\text { Hocquigny et al., 2004; } \\
\text { Walker et al., 2006; Furiya et al., } 2009\end{array}$ \\
\hline & Pinot blanc & White-skinned berries & $\begin{array}{l}50 \text { SSR/bud sport } \\
\text { of Pinot gris }\end{array}$ & $\begin{array}{l}\text { Hocquigny et al., 2004; } \\
\text { Walker et al., 2006; Yakushiji et al., } 2006\end{array}$ \\
\hline \multirow[t]{3}{*}{ Savagnins } & Savagnins blanc & $\begin{array}{l}\text { White-skinned berries/ } \\
\text { neutral aroma }\end{array}$ & & \\
\hline & Savagnins rose & $\begin{array}{l}\text { Rosy-skinned berries / } \\
\text { neutral aroma }\end{array}$ & $16 \mathrm{SSR}$ & Duchêne et al., 2009 \\
\hline & Gewurztraminer & $\begin{array}{l}\text { Rosy-skinned berries/ } \\
\text { aromatic }\end{array}$ & $16 \mathrm{SSR}$ & \\
\hline \multirow[t]{2}{*}{ Ugni blanc } & Ugni blanc & Fleshy berries & & \\
\hline & Fleshless mutant & Fleshless berries & Bud sport of Ugni blanc & Fernandez et al., 2006 \\
\hline
\end{tabular}

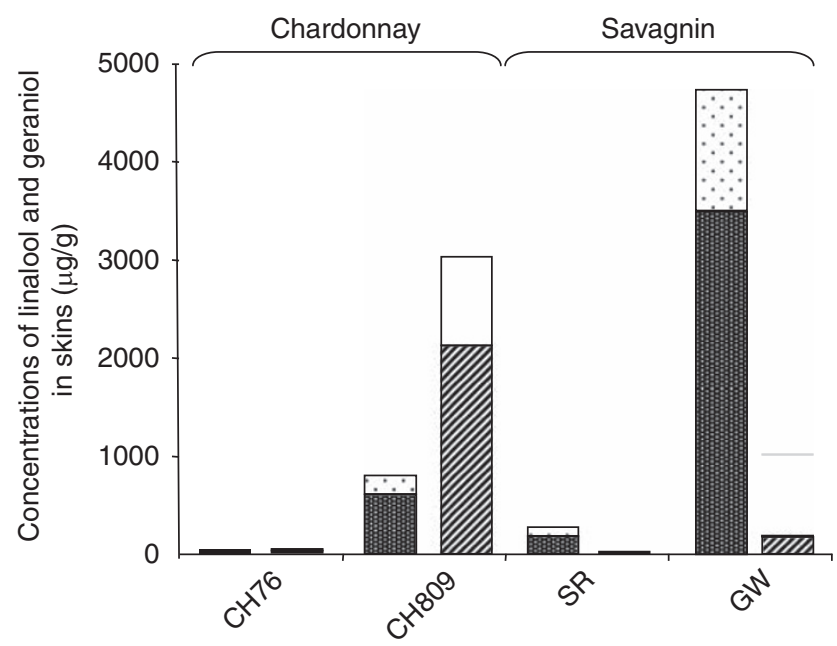

Figure 1 Geraniol and linalool concentrations in two pairs of clones: Chardonnay (CH76 and CH809) and Savagnin (Savagnin rose (SR) and Gewurztraminer (GW)). Concentrations of geraniol (left) and linalool (right) were measured in the skins of mature berries according to Duchêne et al. (2009). Dark pattern: glycosylated form, light pattern: free form.

The third one, Brasil, is a black-skinned and red-fleshed berried cultivar started from a bud sport of Benitaka (Oliveira Collet et al., 2005).
Research on grape berry color has identified the association of a lack of anthocyanin pigment with the insertion of Gret1, a 10422 bp long retrotransposon, in the promoter region of $V v m y b A 1$, a gene encoding a transcription factor that induces the anthocyanin pathway (Kobayashi et al., 2004). This large insertion separates the VvmybA1 coding sequence from its promoter and impairs its transcription. Kobayashi et al. showed that all colored varieties, including Pinot noir and Cabernet Sauvignon, are heterozygous at the berrycolor locus where the allele mutated by the Gret1 insertion (white allele) and the functional allele (red allele) are both present. Conversely, all white varieties were found to be homozygous for the white allele. It was further shown that the berry-color locus is a cluster of Myb and Myb-like genes spanning a 200-kb region located on chromosome 2 (Azuma et al., 2009). Among these, both $V v m y b A 1$ and $V v m y b A 2$ genes control berry color. The white allele is characterized by mutations in $V v m y b A 1$ and $V v m y b A 2$ in which the loss of transcription factor expression prevents anthocyanin biosynthesis (Walker et al., 2007).

Recently, the clonal difference between a black-skinned Pinot noir and a white-skinned Pinot blanc was shown to be caused by a large deletion, over $260-\mathrm{kb}$ long, that removed both functional $V v m y b A$ genes of the red allele, leading to the white phenotype of Pinot blanc (Walker et al., 2006; Yakushiji et al., 2006). Similarly, a large 

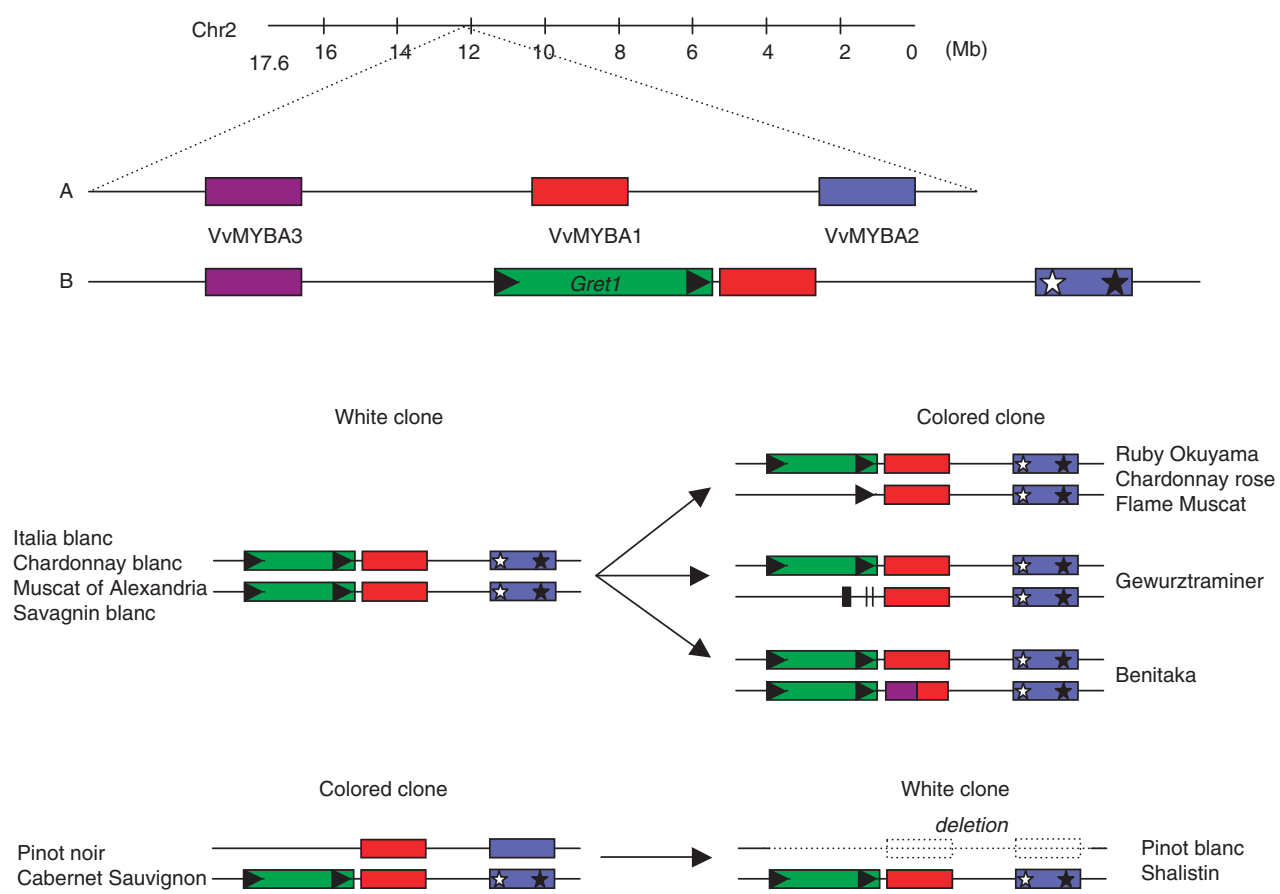

Figure 2 Diagrammatic position of three $V v m y b A$ genes on grape chromosome 2 according to Azuma et al. (2009). (Not to scale). (a and b) colored and white locus, respectively. Stars represent non-conservative changes identified in the VvmybA2 white sequence as compared with the $V v m y b A 2$ colored sequence. Structures of the different alleles and genotypes of the clones were deduced from the published data.

deletion in the red allele of Cabernet Sauvignon is responsible for the white-berried phenotype of Shalistin, a bud sport of Cabernet Sauvignon (Walker et al., 2006) (Figure 2).

On rare occasions, white-berried varieties have produced light-red-berried bud sports. For example, Chardonnay and Sultana have produced bud sports called red Chardonnay and pink Sultana, respectively (Boss et al., 1996). Both of these varieties had a berry-color locus allele whose insertion in the promoter region of VvmybA1 was shorter than the full-length Gret1 copy. The pink-berried sport Chardonnay rose showed a new allele with a 829-bp-long insertion corresponding to the Gret1 3'LTR, instead of the white allele with the fulllength Gret1 insertion found in white-berried clone Chardonnay blanc (Walker et al., 2006). This smaller insertion could allow some expression of the VvmybA1 gene, leading to the pink color of the berries (This et al., 2007) (Figure 2). The same alteration has been found in the red-skinned Ruby Okuyama and Flame Muscat, two bud sports from the green-skinned Italia and whiteskinned Muscat d'Alexandria clones, respectively. Both red-skinned varieties have a new allele derived from the white allele with the Gret1 solo-LTR. Given that it is flanked by a 5-bp duplication target site that signals retrotransposon insertion, the remaining Gret1 solo-LTR most likely resulted from the partial excision of Gret1 by intra-LTR recombination (Kobayashi et al., 2004). Sequencing the solo-LTR from colored variants of different table grape varieties, Lijavetzky et al. (2006) have shown that recombination events have taken place at different positions within the LTRs (Lijavetzky et al., 2006). Another type of mutation has been identified in Gewurztraminer, a pink-skinned cultivar of Savagnin blanc, which has an allele with a 44-bp-long insertion upstream from the promoter, followed by two singlenucleotide polymorphisms compared with the red allele (This et al., 2007). This new allele, which is derived from the white allele by an as-yet unknown mechanism, allows the partial expression of the VvmybA1 gene. In Benitaka, Azyma et al. showed that color recovery was also due to a new allelic form of $V v m y b A 1$. The new allele contains a region in $5^{\prime}$ of $V v m y b A 1$ that originated from $V v m y b A 3$, a paralogous gene belonging to the same cluster, which restores $V v m y b A 1$ functionality although the full Gret1 copy remains in its original insertion site. These authors hypothesize that the Benitaka VvmybA1 gene was formed by illegitimate homologous recombination between $V v m y b A 1$ and $V v m y b A 3$ (Azuma et al., 2009) (Figure 2). According to Oliveira Collet et al., the mutation from Italia to Benitaka occurred only once, but phenotypic reversions from Benitaka to Italia are more frequently observed in Brazilian vineyards (0.4\%) (Supplementary Material 1a) (Oliveira Collet et al., 2005). Single-nucleotide polymorphisms are another source of phenotypic variation. The dwarf phenotype of regenerated plants from Pinot meunier is associated with an altered response to gibberellins. Studying the $V v G A I 1$ gene, which encodes a negative regulator of the gibberellins response, Boss and Thomas (2002) identified a point mutation in the DELLA domain of one of the VvGAI1 alleles. This mutation converts a leucine residue of the conserved DELLA domain into histidine. The change from a small hydrophobic leucine residue into a larger basic histidine residue seems to alter the gibberellin-response properties of the protein. This dominant mutation causes the dwarf phenotype of the regenerated plants (Boss and Thomas, 2002).

The cases described above show that clonal polymorphism can result from single-nucleotide polymorphisms, 
from size polymorphism of several microsatellite loci, from partial excision of the retrotransposon Gret1 by intra-LTR recombination, from illegitimate recombination between paralogous genes, or from large deletions by unknown mechanisms, but not from mobile element insertion per se.

As transposable elements are mobile genomic entities that can insert new copies around the host genome, the movement of transposable elements during vegetative propagation has been analyzed. Transposition mutations can have tremendous effects on genome structure and gene function, especially when genes and regulatory factors are affected (Biémont and Vieira, 2006). A majority of the work on transposable elements has focused on retrotransposons that spread through a copy-and-paste cycle, because their proliferation can be triggered by stress and environmental factors such as wounding or harsh climatic conditions (Grandbastien, 1998). As a grapevine is a perennial plant that may be strongly stressed during long productive growth by grafting, pruning, pathogen attack or ultraviolet irradiation, retrotransposons may contribute to grapevine genomic plasticity. Three retrotransposons were characterized before the grapevine genome was sequenced: Vine-1 (Verriès et al., 2000), Tvv1 (Pelsy and Merdinoglu, 2002) and Gret1 (Kobayashi et al., 2004). Vine-1 insertion polymorphism was analyzed in six clones of Pinot and three clones of Traminer (another name for Savagnin) by S-SAP fingerprinting. The three Savagnin clones could be distinguished by Vine-1 insertion polymorphism, but the six Pinot clones could not, despite their different color phenotypes (Labra et al., 2004). The S-SAP polymorphism could result either from a new insertion of the transposable element or from a modification of the restriction site (for example, single-nucleotide polymorphism). Thus, it not yet possible to conclude whether Vine-1 or another mobile element is responsible for phenotypic clonal variations during vegetative propagation. The recent extensive inventory of transposable elements, which compose $41.4 \%$ of the grapevine genome (Jaillon et al., 2007), should increase the chance of finding mobile elements involved in clonal polymorphism (Benjak et al., 2008; Moisy et al., 2008).

\section{Chimerism}

Plants have many developmental characteristics that result in the accumulation of somatic mutations: lack of a germline, open systems of growth and flexible meristem organizations (Klekowski and Godfrey, 1989). A majority of the dicotyledonous plants have stratified apical meristems containing up to three layers of dividing cells. Each cell layer remains developmentally independent from the adjacent layers and gives rise to different plant tissues: L1 to the epidermis and L2 and L3 to internal tissues (Neilson-Jones, 1969). As a consequence of this stratified meristem, most somatic mutations are not immediately life-threatening in plants (Klekowski and Godfrey, 1989). During plant development, a mutation in one cell of a layer of the shoot apical meristem propagates by mitosis and produces a mutated sector (D'Amato, 1977). Periclinal chimeras are a specific type of genetic mosaic in which one or two entire cell layers of the apical meristem are genetically distinct and remain developmentally independent from the adjacent layers (Dermen, 1960).

Chimerism in grapevines was first shown in the cell layers of shoot apical meristems of varying ploidy. In these structures, named 'cytochimeras', grapevine apical meristems appear to be composed of two genetically distinct cell layers, L1 and L2 (Einset and Pratt, 1954; Thompson and Olmo, 1963). Grapevines are a diploid species, but it is known to be highly heterozygous. Using the co-dominant determination of microsatellite markers, Franks et al. (2002) observed three alleles instead of the two expected at a locus in some clones of the Champagne Pinot meunier, which is thought to be a mutant variety of Pinot noir (Bowers et al., 1999), and have identified periclinal chimerism as the source of this anomaly (Franks et al., 2002). These authors have shown that when the two cell layers of the periclinal chimera are separated by passage through somatic embryogenesis, the regenerated plants not only have distinct DNA profiles different from those of the parental plant but also have novel phenotypes. After separation of the two cell layers of Pinot meunier, the plants regenerated from the L1 cell layer showed dwarfism and showed the hairy leaf phenotype of Pinot meunier. Moreover, these L1 dwarf plant produced inflorescences and bunches along the length of the shoots instead of tendrils. Plants regenerated from the L2 cell layer, on the other hand, were phenotypically indistinguishable from Pinot noir and produced tendrils (Boss and Thomas, 2002). Three similar but distinct sequences in the VvGAI1 locus of the parental Pinot meunier were identified, indicating a chimeric structure. L1- and L2-regenerated plants each possessed only two of the three alleles; one allele was common to both plants, whereas the other differed between L1 and L2 plants solely by the presence of the point mutation in the DELLA domain of the VvGAII gene, which caused the dwarf phenotype of the L1regenerated plants (Boss and Thomas, 2002).

Somatic chimerism is quite common in grapevines. Three- and sometimes four-allele genotypes, indicating chimeric structures, have been detected using microsatellite markers in a wide range of varieties, including Primitivo (Franks et al., 2002), Greco di Tufo and Corvina veronese (Crespan, 2004), Cabernet Sauvignon (Moncada et al., 2006), Pinot (Hocquigny et al., 2004), Cabernet franc, Chenin, Grolleau, Riesling and Savagnin (Pelsy et al., submitted). Three alleles at a locus can be explained by a chimeric structure consisting of two cell layers having genotypes associating one common and one specific allele of each layer, whereas a four-allele locus is due to two completely different genotypes in each layer. The occurrence of chimeric structures can be independently confirmed by analyzing the genotypes of the L1 and L2 cell layers after splitting the chimera through somatic embryogenesis. Alternatively, the genotypes of the different cell layers can be determined by studying sexual progeny or tissues such as roots, because both roots and gametes of grapevines are descended from the L2 inner tissues. Chimerism was confirmed for the certified Chardonnay clone 96 (Bertsch et al., 2005) as well as for the fleshless berry mutant of Ugni blanc (Fernandez et al., 2006). Two certified clones of Pinot gris, PG52 and PG53, were also shown to be chimeras. However, although PG52 showed a tri-allele profile at two of the 50 microsatellite loci studied, PG53 did not 


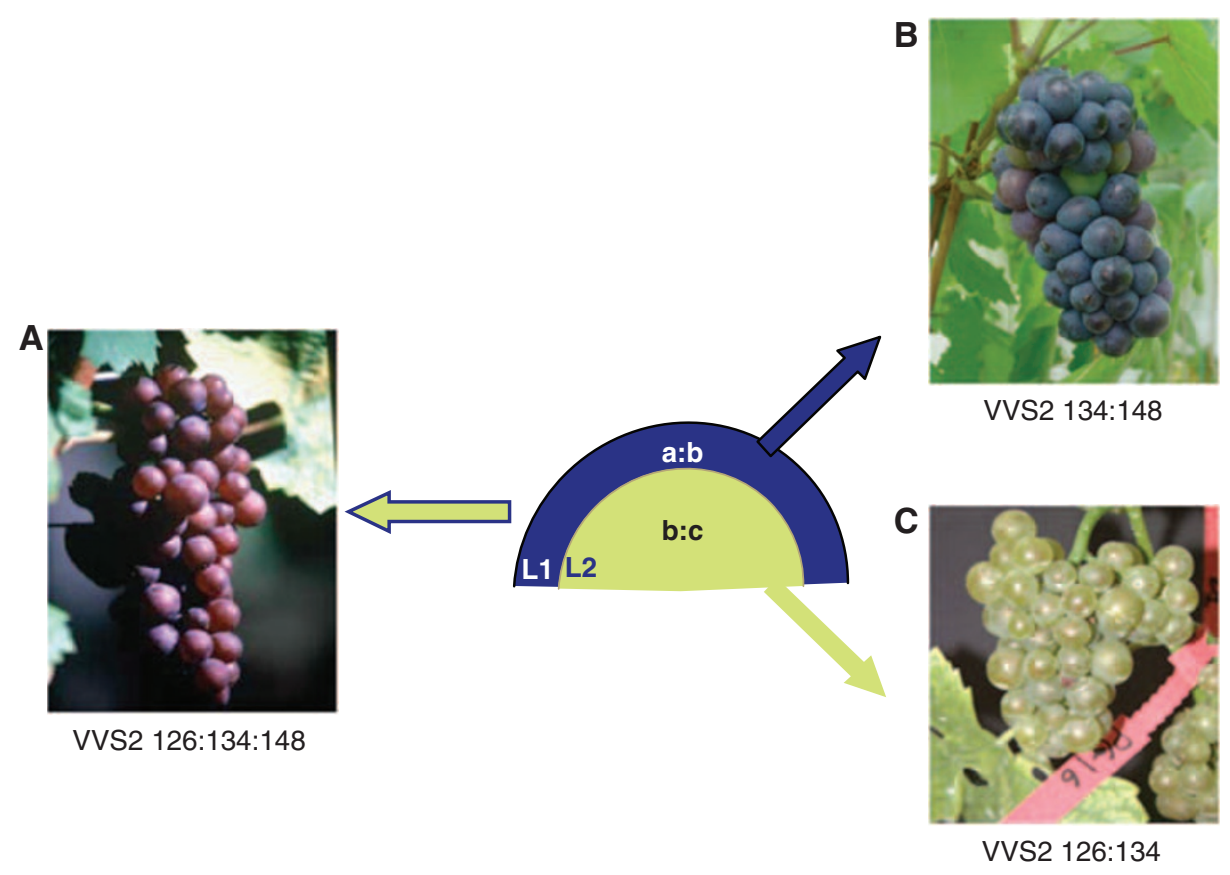

Figure 3 Diagrammatic representation of the two cell layers of Pinot gris. Phenotypes and genotypes at VVS2 of Pinot gris PG52 (A), a plant regenerated from the PG52 L1 cell layer by somatic embryogenesis (B) and a self-progeny of PG52 heterozygous at locus VVS2 (C). (a) Allele specific to the L1 cell layer (148 at locus VVS2); (b) common allele of both cell layers (134 at locus VVS2) and (c) allele specific to the L2 cell layer (126 at locus VVS2).

show any (Hocquigny et al., 2004). All self-progenies of both PG52 and PG53 produced only white-berried plants, whereas all PG52 and PG53 plants regenerated from the L1 cell layer and brought to fructification produced black berries (F Pelsy et al., unpublished data). Thus, the grey-colored berry phenotype of PG52 and PG53 could result from a chimeric structure composed of a colored L1 epidermis and L2 cells with a mutation in the color locus that prevents anthocyanin synthesis (Figure 3). This hypothesis was recently confirmed in the berry cell layers of Pinot noir and Pinot gris. Oblique sections of nearly ripe berries of Pinot noir revealed colored cells in the epidermis and in several layers of subepidermal cells in the skin of the berry, whereas only epidermal cells were pigmented in Pinot gris berries (Walker et al., 2006). Similarly, the dark red-berried Cabernet Sauvignon has several layers of colored cells, extending from the epidermal layer into the flesh of the berry, whereas Malian, whose color phenotype resembles that of Pinot gris, contains anthocyanin only in the epidermis (Walker et al., 2006).

Thus, the only way to propagate true-to-type chimeras whose phenotypes result from $\mathrm{L} 1 \times \mathrm{L} 2$ interaction is by vegetative propagation through bud organogenesis, for example, stem cutting, layering or bud grafting, as somatic embryogenesis allows the transmission of the genotype of only one of the two cell layers of the chimera.

\section{Cellular rearrangements}

The stability of chimeric structures in grapevines is attested by the constant use of Pinot meunier and Pinot gris in France since the seventeenth century (Rézeau, 1998). However, chimeras sometimes show instability. Occasionally, Pinot meunier leaves with hairless sectors or entire glabrous shoots are observed on individual vines. Using one microsatellite marker containing three alleles of Pinot meunier, Franks et al. (2002) showed that the hairless sectors had a new di-allelic genotype corresponding to the L2 cell layer. Pinot gris also occasionally produces colored berries with white variegations (Hocquigny et al. 2004). The grey-berried Malian produces canes with white fruit at a frequency of 1-2 per thousand vines per year, a genetic instability much higher than the reversion rate of white-berried Shalistan to red (Walker et al. 2006). Occurrence of black sectors in Benitaka, which originated the Brasil cultivar, was detected in five vines from three Benitaka vineyards during the 1995-2002 period. Moreover, phenotypic reversions from Brasil to Benitaka are observed with a high frequency $(28.57 \%)$. The mechanism leading to the Brasil phenotype from Benitaka is still unknown, but because of its instability, Oliveira Collet et al. suggested that Brasil is a periclinal chimera (Oliveira Collet et al., 2005).

The phenotypic instability of chimeric plants can account for cellular rearrangements in the chimera. An invasion by cells from the inner layers into the outer L1 layer, termed 'displacement', can occur owing to the low level of organization of cell division in the inner layers (Stewart and Dermen, 1970). Such an event, which may follow damage caused by herbivores (meristem destruction), uncovers mutations earlier sequestered in one cell layer (Marcotrigiano, 2000). Thus, the loss of trichomes on the leaf surface of Pinot meunier could result from the replacement of the L1 epidermal layer, showing the hairy leaf phenotype, by hairless L2 cells (Franks et al., 2002). In a partially colored berry of Pinot gris PG52 (Figure 4a), the colored skin sector was found to have the triallelic combination identical to the leaf at the VVS2 locus, whereas the white skin sector showed the diallelic 

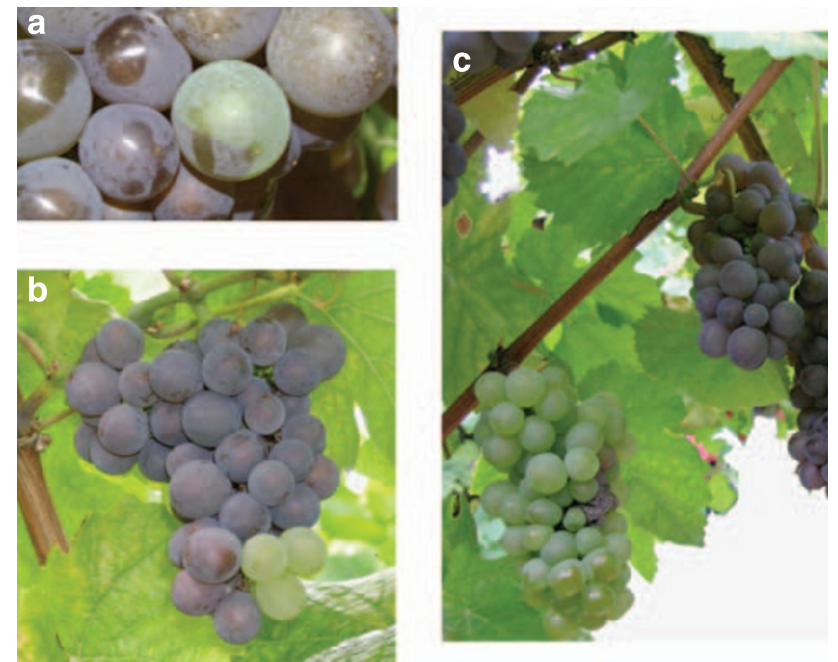

Figure 4 Examples of white-berried variegations on a Pinot gris berry (a), bunch (b) and cane (c).

combination transmitted to the self-progenies. A displacement from the L2 cell layer to the L1 could be responsible for generating the white-berried sector on Pinot gris berries. Such displacements can affect a few berries or a whole bunch on a cane, according to the development stage during which the displacement occurs (Figures $4 \mathrm{~b}-\mathrm{c}$ ).

Somatic mutations can thus propagate to the whole plant by a two-step process. In the first step, a somatic mutation arises in one cell of the shoot apical meristem, and then the mutation spreads by cell division to an entire cell layer, creating a stable chimeric structure. In the second step, the replacement of one cell layer by another can lead to a homogenization of the genotype of the whole plant (Hocquigny et al., 2004). This two-step process can account for the appearance of new diallelic combinations in Pinot noir at different loci (Riaz et al., 2002). Displacement may have occurred to generate a white-berried phenotype from Pinot gris or Malian through the invasion of epidermal colored cells (L1) by subepidermal white cells (L2) mutated at the berry-color locus by deletions, as described earlier (Hocquigny et al., 2004; Walker et al., 2006). Thus, a bud sport of Pinot gris or Malian bearing only white berries could give rise to a Pinot blanc or Shalistin clone when vegetatively propagated.

In comparison, Pinot noir vines were examined for mutations that resulted in white fruit, but no changes of this type have been found (Müller-Stoll, 1950). As two alterations would be required to convert black Pinot noir berries to white berries, it is not surprising that white berries have not been observed. Once a deletion is established in both cell layers, reversion to bronze or black is not likely to occur through an alteration in cell position, because the red berry color allele has been deleted from the clone (Walker et al., 2006). The opposite phenomenon, L1 cell invasion of the inner layer, a process called 'replacement', is accepted as being rare in angiosperms, owing to the stability of the anticlinal cell divisions. However, cases of black berries and black berry sector have been observed in Pinot gris bunches (Supplementary Material 1b). Instead of cellular rearran-
Clonal variability in grapevines

F Pelsy

gements, an entirely different mechanism could explain the appearance of a bud sport in Pinot gris. Deletions of the red allele at the color locus could have occurred independently in the L1 and the L2 cell layers, a hypothesis that is supported by the triallelic profile observed at the microsatellite locus VVMD32 in both a Pinot gris vine and its white bud sport (Furiya et al., 2009).

\section{Factors driving clone evolution}

The ability of clones to evolve is a critical concern for wine growers who use vegetative propagation to perpetuate virtually identical clones over time. One way to evaluate clones' ability to evolve is based on the evaluating the diversity level within varieties. First, the range of clonal diversity would depend on the age of the variety; the more ancient the variety, the longer it would have been exposed to environment stresses and the longer it would have been accumulating mutations. However, it is very difficult to establish when the seed, giving rise to the ancestral seedling of a variety was germinated. Only hypotheses based on historical documents can be put forward. For instance, Pinot is thought to be among the most ancient of varieties. At the time of the Roman conquest of France, the Roman agricultural writer Columella described a variety in Burgundy that is consistent with the properties of Pinot noir (Viala and Vermorel (1901-1910). Moreover, Pinot and Savagnin show primitive morphological characteristics analogous to those of the wild-type ssp. silvestris, and are thus considered 'archaic' varieties (Levadoux, 1956). Tri-allelic polymorphism is frequently observed between clones of Pinot or Savagnin. In contrast, no triallelic combinations were found at 14 loci in Muscat Ottonel, a variety obtained during the nineteenth century (Bronner, 2003). Second, various environmental conditions of stress, could favor the occurrence of spontaneous somaclonal mutations. For example, Cabernet Sauvignon was first cited in a French seventeenth-century document (Viala and Vermorel, 1901-1910), and its origin as a progeny of Cabernet franc and Sauvignon blanc is now well established (Bowers and Meredith, 1997). Currently, Cabernet Sauvignon is cultivated in many countries around the world (Galet, 2000), including Chile where it was introduced by don Silvestre Ochagavia in 1851. Intravarietal genetic diversification associated with geographical dispersal of 59 Cabernet Sauvignon clones obtained from seven countries was analyzed using microsatellite markers (Moncada et al., 2006). Only two clones (one from France and one from Australia) presented the ancestral genotype deduced from Cabernet Sauvignon parental genotypes, whereas all others shared the same triallelic profile at microsatellite locus VMC5g7. The molecular results support the hypothesis that the origin center of Cabernet Sauvignon is France, where mutation at VMC5g7 would have taken place before the 1850s and subsequently has been dispersed to other countries. The two largest sets of clones from France and Chile that were studied showed a clear divergence in the polymorphisms; thus, it is most likely that vines in Chile diverged independently from the French pool after the 1850s. Third, high clonal diversity may reflect the longterm interest of vine growers and winemakers to select clones with particular characteristics such as color and 
flavor, as observed for Savagnin. However, the possibility that some varieties have a stronger proclivity toward spontaneous mutations in the vineyard owing to a particular genetic background cannot be excluded.

\section{Maintaining clonal diversity}

The genetic diversity within a variety depends first on its ability to accumulate mutations over time, and then on the survival of the mutants after annual pruning and propagation by growers. Thus, the present diversity in varieties results from both genetic and anthropic pressure. Two main causes are responsible for the drastic reduction in diversity within varieties during the last 140 years. The first is the severe phylloxeric crisis because of the aphid Phylloxera vastatrix, known to modern science as Daktulosphaira vitifoliae, which has caused devastation in European vineyards since 1865. European varieties belonging to the species $V$. vinifera that were susceptible to phylloxera were saved by grafting onto resistant American rootstocks. However, only a small number of clones were rescued to reconstitute vineyards, reducing the diversity present before the phylloxeric crisis (Pouget, 1990).

The second cause of diversity loss has been the selection of a reduced number of elite clones within each variety, originally conducted to improve vineyards. The first selection, made in Germany on the basis of visual selection, led to the certification of the first elite clones in 1896 (Huglin and Schneider, 1998). In France, clonal selection began in the 1960s, with both sanitary and genetic objectives. The selection of each clone was based on evaluation of the viticultural characteristics and sanitary status of the existing plants of each variety. This rigorous selection resulted in a limited number of certified clones for each variety, each registered under a unique number. Now, more than $90 \%$ of French vineyards are planted with certified clones (Vinifhor, 2007). However, exclusively planting a small number of elite clones threatens clonal diversity. To preserve the diversity that still exists in ancient grapevine plots, prospecting has been carried out in France since the 1970 s and regional repositories have been established. Such repositories exist around the world and include at least 85 varieties in France (Audeguin et al., 1998). In addition to preserving clonal diversity, these collections provide a resource for understanding the way that clonal diversification has occurred within each variety. Moreover, thanks to their high similarity level, clones with particular phenotypic characters could provide plant material suitable for functional genomics studies.

\section{Conclusions}

Intra-varietal diversity is the result of a series of rare events. A somatic mutation must first occur in a cell that is, or will become, part of the shoot meristem, which must then multiply to form a distinct cell layer of that meristem. If it is formed, the periclinal chimera must survive the annual pruning of shoots and be selected for vegetative propagation. In chimeric states and through cellular rearrangements, the genotypes of clones drift over time, creating diversity. Thus, varieties are in slow but constant evolution, as exemplified by Chilean
Cabernet Sauvignon clones, which have evolved independently from the French clones over the last 150 years.

Up to now, only a few mutations have been shown to be responsible for clonal polymorphisms including a point mutation in the DELLA domain of the VvGAI1 gene in the LI cell layer of Pinot meunier, large deletions of the color-berry locus responsible for the loss of anthocyanin biosynthesis in different varieties, illegitimate recombination and size polymorphism of several microsatellite loci. Thus, most of the molecular mechanisms underlying clonal variation are still unknown. The recent release of the grapevine whole-genome sequence provides a framework for rapid characterization of all types of polymorphism that arise during vegetative propagation through comparison of the sequences of different clones belonging to a same variety (Jaillon et al., 2007). On the basis of such exhaustive information, new specific tools should be developed to deeply analyze grapevine germplasm collections and to definitively identify clones in different varieties.

\section{Conflict of interest}

The authors declare no conflict of interest.

\section{Acknowledgements}

I am grateful to Eric Duchene for Figure 1 and for careful reading of the paper and to Maria de Fatima Machado for the picture of the Benitaka bunch. I also thank Didier Merdinoglu and Christian Biemont for suggestions on how to improve the paper.

\section{References}

Alleweldt G, Dettweiler E (1994). The genetic resources of Vitis: world list of grapevine collections, 2nd edn. BAZ IRZ Geilweilerhof, Siebeldingen.

Aradhya MK, Dangl GS, Prins BH, Boursiquot JM, Walker MA, Meredith CP et al. (2003). Genetic structure and differentiation in cultivated grape, Vitis vinifera L. Genet Res 81: 179-191.

Arroyo-Garcia R, Ruiz-Garcia L, Bolling L, Ocete R, Lopez MA, Arnold C et al. (2006). Multiple origins of cultivated grapevine (Vitis vinifera L. ssp sativa) based on chloroplast DNA polymorphisms. Mol Ecol 15: 3707-3714.

Audeguin L, Boidron R, Leclair P, Boursiquot JM (1998). Les conservatoires de clones de cépages de cuve en France. Etat des lieux, méthodologie et perspectives. Progr Agric Vitic 23: 115.

Azuma A, Kobayashi S, Goto-Yamamoto N, Shiraishi M, Mitani N, Yakushiji H et al. (2009). Color recovery in berries of grape (Vitis vinifera L) Benitaka', a bud sport of 'Italia', is caused by a novel allele at the VvmybA1 locus. Plant sci 176: 470-478.

Benjak A, Forneck A, Casacuberta JM (2008). Genome-wide analysis of the 'cut-and-paste' transposons of grapevine. PLOS ONE 3: e3107.

Bertsch C, Kieffer F, Maillot P, Farine S, Butterlin G, Merdinoglu $\mathrm{D}$ et al. (2005). Genetic chimerism of Vitis vinifera cv. Chardonnay 96 is maintained through organogenesis but not somatic embryogenesis. BMC Plant Biol 5: 1-7.

Biémont C, Vieira C (2006). Genetics: junk DNA as an evolutionary force. Nature 443: 521-524.

Boss PK, Davies C, Robinson SP (1996). Anthocyanin composition and anthocyanin pathway gene expression in grapevine sports differing in berry colour. Aust J Grape Wine Res 2: 163-170. 
Boss PK, Thomas MR (2002). Association of dwarfism and floral induction with a grape 'green revolution' mutation. Nature 416: 847-850.

Boursiquot JM, This P (1999). Essai de définition du cépage. Progr Agric Vitic 116: 359-361.

Bowers J, Meredith C (1997). The parentage of a classic wine grape, Cabernet Sauvignon. Nat Genet 16: 84-87.

Bowers JE, Boursiquot JM, This $\mathrm{P}, \mathrm{Chu} \mathrm{K}$, Johansson $\mathrm{H}$, Meredith CP (1999). Historical genetics: the parentage of Chardonnay, Gamay, and other wine grapes of northeastern France. Science 285: 1562-1565.

Bronner A (2003). Muscats et variétés muscatées. Inventaire et synonymie universels, des origines à nos jours. INRA editions: Oenoplurimedia.

Crespan M (2004). Evidence on the evolution of polymorphism of microsatellite markers in varieties of Vitis vinifera L. Theor Appl Genet 108: 231-237.

D'Amato F (1977). Nuclear Cytology in Relation to Development. Cambridge University Press: Cambridge.

Dermen H (1960). Nature of plant sports. Am Horticult Magazine 39: 123-173.

Duchêne E, Legras J-L, Karst F, Merdinoglu D, Claudel P, Jaegli $\mathrm{N}$ et al. (2009). Variation of linalool and geraniol content within two pairs of aromatic and non aromatic grapevine clones. Aust J Grape Wine Res 15: 120-130.

Einset J, Pratt C (1954). 'Giant' sports of grapes. Proc Am Soc Horticult Sci 63: 251-256.

Eisen JA (1999). Mechanistic basis for microsatellite instability. In: Goldstein DB, Schlötterer C (eds). Microsatellites-Evolution and Applications, pp 34-48. Oxford University Press: Oxford.

Ellegren H (2004). Microsatellites: single sequences with complex evolution. Nat Rev Genet 5: 435-445.

Fernandez L, Doligez A, Lopez G, Thomas MR, Bouquet A, Torregrosa L (2006). Somatic chimerism, genetic inheritance, and mapping of the fleshless berry (flb) mutation in grapevine (Vitis vinifera L). Genome 49: 721-728.

Franks T, Botta R, Thomas MR (2002). Chimerism in grapevines: implications for cultivar identity, ancestry and genetic improvement. Theor Appl Genet 104: 192-199.

Furiya T, Suzuki S, Sueta T, Takayanagi T (2009). Molecular characterization of a bud sport of Pinot gris bearing white berries. Am J Enol Vitic 60: 66-73.

Galet P (2000). Dictionnaire encyclopédique des cépages. Hachette Editions.

González-Techera A, Jubany S, De Leon I, Boido E, Dellacassa E, Carrau $\mathrm{F}$ et al. (2004). Molecular diversity within clones of $\mathrm{cv}$. Tannat (Vitis vinifera). Vitis 43: 179-185.

Grandbastien M-A (1998). Activation of plant retrotransposons under stress conditions. Trends Plant Sci 3: 181-187.

Hartmann HT, Kester DE, Davis Jr FT, Geneve RL (2001). Plant Propagation: Principles and Practices, 7th edn. Prentice Hall: Upper Saddle River, NJ, USA. 880pp.

Hocquigny S, Pelsy F, Dumas V, Kindt S, Héloir MC, Merdinoglu D (2004). Diversification within grapevine cultivars goes through chimeric states. Genome 47: $579-589$.

Huglin P, Schneider C (1998). Biologie et écologie de la vigne. Lavoisier Tec \& Doc: Paris.

Institut Français de la Vigne et du Vin (2007). Catalogue des variétés et clones de vigne cultivés en France. Le Grau du Roi: France.

Jaillon O, Aury J-M, Noel B, Policriti A, Clepet C, Casagrande A et al. (2007). The grapevine genome sequence suggests ancestral hexaploidization in major angiosperm phyla. Nature 449: 463-467.

Kaeppler SM, Kaeppler HF, Rhee Y (2000). Epigenetic aspects of somaclonal variation in plants. Plant Mol Biol 43: 179-188.

Klekowski EJ, Godfrey PJ (1989). Ageing and mutation in plants. Nature 340: 389-391.
Kobayashi S, Goto-Yamamoto N, Hirochika H (2004). Retrotransposon-induced mutations in grape skin color. Science 304: 982.

Labra M, Imazio S, Grassi F, Rossoni M, Sala F (2004). Vine-1 retrotransposon-based sequence-specific amplified polymorphism for Vitis vinifera L genotyping. Plant Breed 123: 180-185.

Levadoux L (1956). Les populations sauvages et cultivées de Vitis vinifera L. Ann Amelior Plant 59-119.

Lijavetzky D, Ruiz-Garcia L, Cabezas JA, De Andres MT, Bravo G, Ibanez A et al. (2006). Molecular genetics of berry colour variation in table grape. Mol Genet Genomics 276: 427-435.

Marcotrigiano M (2000). Herbivory could unlock mutations sequestered in stratified shoot apices of genetic mosaics. Am J Bot 87: 355-361.

Merdinoglu D, Butterlin G, Bevilacqua L, Chiquet V, AdamBlondon A-F, Decroocq S (2005). Development and characterization of a large set of microsatellite markers in grapevine (Vitis vinifera L suitable for multiplex PCR. Mol Breed 15: 349-366.

Moisy C, Garrison K, Meredith CP, Pelsy F (2008). Characterization of ten novel Ty1 copia-like retrotransposon families of the grapevine genome. BMC Genomics 9: 469.

Moncada X, Pelsy F, Merdinoglu D, Hinrichsen P (2006). Genetic diversity and geographical dispersal in grapevine clones revealed by microsatellite markers. Genome 49: 1459-1472.

Müller-Stoll W (1950). Mutant colour changes in wine grapes. Der Züchter 20: 288-291.

Neilson-Jones W (1969). Plant chimeras 2nd edn Methuen: London.

Oliveira Collet SA, Collet MA, Machado MdFPS (2005). Differential gene expression for isozymes in somatic mutants of Vitis vinifera L. (Vitaceae). Biochem Syst Ecol 33: 691-703.

Pacottet P (1903). Savagnins. In Ampélographie 301-314.

Pelsy F (2007). Untranslated leader region polymorphism of Tvv1, a retrotransposon family, is a novel marker useful for analyzing genetic diversity and relatedness in the genus Vitis. Theor Appl Genet 116: 15-27.

Pelsy F, Hocquigny S, Moncada X, Barbeau G, Forget D, Hinrichsen $\mathrm{P}$ et al. (submitted) An extensive study of the clonal genetic diversity within seven French wine grape collections.

Pelsy F, Merdinoglu D (2002). Complete sequence of Tvv1, a family of Ty1 copia-like retrotransposons of Vitis vinifera L reconstituted by chromosome walking. Theor Appl Genet 105: 614-621.

Pouget R (1990). Histoire de la lutte contre le phylloxéra de la vigne en France (1868-1895). INRA: Paris.

Renault-Spilmont A-S, Grenan S, Boursiquot JM (2007). Syrah decline in French vineyards: Rootstocks and Syrah clone impact, pathological and genetic studies. Proceedings of the Syrah Vine Health Symposium. University of California: Davis. pp 5-7.

Rézeau P (1998). Dictionnnaire des noms de cépages en France. Histoire et éthymologie. CNRS editions: Paris.

Riaz S, Garisson KE, Dangl GS, Boursiquot JM, Meredith CP (2002). Genetic divergence and chimerism within ancient asexually propagated winegrape cultivars. J Am Soc Hortic Sci 127: 508-514.

Robinson J (2006). The Oxford Companion to Wine, 3rd edn. Oxford University Press: USA.

Sefc KM, Lefort F, Grando MS, Scott KD, Steinkellner H, Thomas MR (2001). Microsatellite markers for grapevine: a state of the art. Mol Biol Biotechnol Grapevine 463: 433-463.

Smith SA, Donoghue MJ (2008). Rates of molecular evolution are linked to life history in flowering plants. Science 322: 86-89.

Stewart RN, Dermen H (1970). Determination of number and mitotic activity of shoot apical initial cells by analysis of mericlinal chimeras. Am J Bot 57: 816-826. 
This P, Jung A, Boccacci P, Borrego J, Botta R, Costantini L et al. (2004). Development of a standard set of microsatellite reference alleles for identification of grape cultivars. Theor Appl Genet 109: 1448-1458.

This P, Lacombe T, Cadle-Davidson M, Owens CL (2007). Wine grape (Vitis vinifera L.) color associates with allelic variation in the domestication gene VvmybA1. Theor Appl Genet 114: 723-730.

Thomas M, Scott N (1993). Microsatellite repeats in grapevine reveal DNA polymorphisms when analysed as sequencetagged sites (STSs). Theor Appl Genet 86: 985-990.

Thompson MM, Olmo HP (1963). Cytohistological studies of cytochimeric and tetraploid grapes. Am J Botany 50: 901-906.

Verriès C, Bès C, This P, Tesnière C (2000). Cloning and characterization of Vine-1, a LTR- retrotransposon-like element in Vitis vinifera L and other Vitis species. Genome 43: 366-376.

Viala P, Vermorel V (1901-1910). Ampélographie. Masson: Paris.
Vinifhor (2007). Bois et plant de vigne. In Annual Report.

Walker AR, Lee E, Bogs J, McDavid DAJ, Thomas MR, Robinson SP (2007). White grapes arose through the mutation of two similar and adjacent regulatory genes. Plant J 49: 772-785.

Walker AR, Lee E, Robinson SP (2006). Two new grape cultivars, bud sports of Cabernet Sauvignon bearing pale-coloured berries, are the result of deletion of two regulatory genes of the berry color locus. Plant Mol Biol 62: 623-635.

Walter B, Martelli GP (1998). Considerations on grapevine selection and certification. Vitis 37: 87-90.

Yakushiji H, Kobayashi S, Goto-Yamamoto N, Tae Jeong S, Sueta T, Mitani N et al. (2006). A skin color mutation of grapevine, from black-skinned Pinot Noir to white-skinned Pinot Blanc, is caused by deletion of the functional VvmybA1 allele. Biosci Biotechnol Biochem 70: 1506-1508.

Supplementary Information accompanies the paper on Heredity website (http://www.nature.com/hdy) 